\title{
The Roles of Sensory Attributes, Functional Benefit, and Brand Ambassador Toward the Brand Loyalty and Repurchase Intention of a Coffee Brand
}

\author{
Christian Haposan Pangaribuan ${ }^{1}$, Putri Paulina², Dairion Thahar ${ }^{3}$
}

${ }^{123}$ Sampoerna University, Jakarta Selatan, Indonesia

\section{A R T I C L E I N F O}

Article history:

Received 17 August 2020

Received in revised form

5 September 2020

Accepted 18 October 2020

Available online 01

November 2020

Keywords:

Sensory Attributes,

Functional Benefits, Brand

Ambassador, Repurchase

Intention, Brand Loyalty

\section{A B S T R A C T}

The trend of drinking coffee has resulted in an increase of coffee consumption around the world, including Indonesia. This study investigates the roles of sensory attributes, functional benefit, and brand ambassador towards the intention to repurchase which leads to brand loyalty of Luwak White Coffee. This study uses a quantitative approach by using primary data and distributed questionnaires to 100 employees of various corporations in Jakarta. The data was analyzed through regression analysis. The result of this study shows that functional benefit has a significant influence on both intentions to repurchase and brand loyalty. This benefit factor is the most important precedent to both repurchase intention and brand loyalty. On the other hand, sensory attributes do not affect repurchase intention. This type of information can be important to predict or to explain the market response to luwak coffee products, and also to select which sensory attribute should be included in a sensory specification or must be considered in product quality control programs. Another important finding is that, contrary to our expectations, we do not find empirical support for the significant influence of brand ambassador on an intention to repurchase and brand loyalty. The explanation may be that customers currently expect the functional benefit in the form of healthier gastric-friendly white coffee. Moreover, the brand ambassador may not be too influential in the high buying decision among luwak coffee consumers. The relevant contributions that emerged from this study include not only bridging the aforementioned gap in the literature but also offering significant managerial implications to assist organizations to understand the importance of functional benefits toward repurchase intention and brand loyalty.

Copyright (C) Universitas Pendidikan Ganesha. All rights reserved.

\section{Introduction}

Indonesia is a developing country with a population of more than 265 million is reported to have an increasing number of coffee consumption in the last 5 years. This phenomenon, demand for consuming coffee, is happening as Indonesia faces the rise of coffee culture and the growth of middle-class families. Indonesian consumption of coffee keeps increasing and was predicted to grow $8.22 \%$ per year during 2016-2021, thus the need for coffee for this country will keep growing (Alfirahmi, 2019; Wijaya et al., 2018).

One of the original coffees from Indonesia, luwak coffee is also known as the most expensive coffee in the world (Barahona et al., 2020). The main difference with the other coffee variants is they use partially digested coffee cherries, eaten and defecated by the Asian palm civet. The local brand Luwak White Coffee, which is the market leader in the Indonesian market use the same Robusta and Arabica coffee beans, with a special process involved, which includes using Japanese technology called cold drying; the coffee beans will be frozen until -40 Celsius. The objective of this process is to eliminate $80 \%$ acid gastric while still maintaining the caffeine $100 \%$. Further, to make sure the consumers can enjoy the gastric-friendly white coffee, Luwak White Coffee removes the acid gastric with cold drying (Harris \& de Chernatony, 2001; Jaimes et al., 2015). 
The success of Luwak White Koffie in the Indonesian market triggered the competitors to produce the same products. Their market share was leading with $68.5 \%$, while the $2^{\text {nd }}$ best was ABC White Coffee with $15.3 \%$. Thus, it can be concluded that the intention to repurchase of Luwak White Coffee is high. In fact, the brand leads the entire major market share several years in a row due to not only because of the good quality products accepted by the Indonesian people but also because of the promotions (e.g. brand ambassador) that company implemented to increase the brand awareness of the customers to trigger the customers to repurchase the product (Gupta \& Stewart, 1996; Gwinner et al., 1998).

As most existing coffee consumption research assumes the sense of social status by "being the part of" (Barahona et al., 2020; Baron \& Kenny, 1986), the aspects of sensory properties of the beverages and the nutritional properties are in urgent need of study. There is a gap of research on consumer behavior insights and solutions that emphasize consumer repurchase intention and brand loyalty at the center of attention. Furthermore, there is a lack of research understanding coffee consumption of luwak coffee products (Curtis et al., 2011; Ko et al., 2011; Wijaya et al., 2018).

This study aims to investigate the behavior outcomes, in terms of intention to repurchase and brand loyalty of Luwak White Coffee, among the employees of various corporations in Jakarta. To define and conceptualize the research construct, the study began with a pre-research of 30 respondents. Ninety percent of the respondents had preferred Luwak White Koffie for the choice of coffee and $50 \%$ of them mentioned the reason because of the taste of the product, which is part of sensory attributes (Orth \& DeMarchi, 2007). Moreover, a concern with the health outcome of the product was deemed important, which turns out that the product was endorsing a good tolerance for gastric. Finally, most of them had opted for the brand because of the advertising and $85 \%$ of them mentioned that the brand ambassador did not affect their purchase decision. Therefore, it is imperative to investigate the subject matter to feed the marketing and brand managers with thoughtful insight for developing mechanisms to improve loyalty to the brand and the reasons behind repetitive purchases of the consumers.

\section{Methods}

In this research, a survey questionnaire was designed according to the objective of the study, and it was used to gather accurate and fewer biased data. The questionnaire involved comprises 6 sections: the demographic characteristics of the respondents on the first section, factors of sensory attributes on the second, functional benefits on the third, brand ambassador on the fourth, repurchase intention on the fifth, and factors of brand loyalty on the last. The last five sections were measured using a five-level Likertscale, ranging from (1) "very unlikely" to (5) "very likely."

The test of the validity of the current study uses Pearson correlation, which compares the value of the correlation to the critical value (Gogtay \& Thatte, 2017). The instruments are valid when the value of the correlation from the research is bigger than the critical value. The result of the validity test of the instrument consisting of 15 items exceeded the lower limit of correlation coefficient of 0.361 . Because the instruments have high validity, it proves that the data collected are valid.

The test of the reliability of this paper uses Cronbach's alpha and the conclusion is that all items were satisfactory because all alpha of the variables exceeded the lower limit of the standard $(>0.70)$ (Taber, 2018). The alpha coefficient for sensory attributes sample item shows the value of 0.870 , functional benefit with 0.868 , brand ambassador is 0.874 , repurchase intention with 0.872 , and brand loyalty with 0.871 . This means that each of the variables exceeded the minimum standard of reliability and hence, can be relied on.

This study includes research preparation, data collection, data processing, and data analysis. A total of 130 questionnaires were distributed among the employees of various corporations, and 100 of them were successfully collected. The respondents were not asked to provide their names nor employee identification numbers. Participants were informed that their responses were known only by the researchers and would be kept confidential. In analyzing the available data, descriptive and inferential statistics were used by utilizing the SPSS software.

Descriptive statistics were used to analyze the respondents' demographic data, i.e. gender, age, monthly expenses, amount of weekly coffee consumption, the familiarity of the Luwak White Coffee brand and whether they had seen a Luwak White Coffee advertisement in the past. The data was presented via frequency and percentage. On the other hand, inferential statistics were used to determine the relationship between the independent and dependent variables. There are 2 statistical models for this study. Model 1 explains the relationship between the 3 independent variables, i.e. sensory attributes (SA), functional benefit (FB), brand ambassador (BA), and 1 dependent variable; intention to repurchase (IR). Model 2 explains the relationship between the 4 independent variables, i.e. SA, FB, BA, IR, and 1 dependent variable; brand loyalty (BL). The research hypotheses were analyzed using regression to 
understand which among the independent variables are related to the dependent variable and to explore the forms of these relationships (Schneider et al., 2010).

\section{Results and Discussions}

Table 1 shows the descriptive statistics of the respondents' demographic characteristics stated in the first section of the questionnaire. Of the total number of the 100 respondents, 34\% of respondents are male and $66 \%$ are female. As for the frequency and percentage of the respondents' age, most of the respondents fall in the age category of under 25 years old (52\%). For weekly expenses, less than IDR 1.00 million is 32\%, IDR 1.00 million - 2.99 million is 36\%, IDR 3.00 million - IDR 4.99 million is $18 \%$, and more than IDR 5.00 million is 14\%. The weekly coffee consumption, mostly 3 to 4 times (38\%), while the second highest is 5 to 6 (34\%). For the familiarity with the Luwak White Coffee brand, most of them said yes (84\%). Finally, whether they had seen a Luwak White Coffee in the past, mostly said yes (82\%).

Table 1. Demographic Characteristics

\begin{tabular}{cll}
\hline Demographic Factor & \multicolumn{1}{c}{ Characteristics } & (\%) \\
\hline \multirow{2}{*}{ Gender } & Male & 34 \\
& Female & 66 \\
Age & $<25$ & 52 \\
& $25-45$ & 38 \\
& $>45$ & 10 \\
Weekly expenses & $<$ IDR 1.00 million & 32 \\
& IDR 1.00-2.99 million & 36 \\
& IDR 3.00 - 4.99 million & 18 \\
Weekly coffee & $>$ IDR 5.00 million & 14 \\
consumption & $1-2$ times & 16 \\
& $3-4$ times & 38 \\
Familiarity of & $5-6$ times & 34 \\
the brand & More than 6 times & 12 \\
Awareness of the & Yes & 84 \\
brand advertisement & No & 16 \\
\hline
\end{tabular}

Table 2. Coefficients of Model 1

\begin{tabular}{lcccc}
\hline Variable & Coefficients & Std. Error & $\boldsymbol{t}$ & Sig. \\
\hline Constant & 0.48 & 0.342 & 0.139 & 0.890 \\
Sensory Attributes & -0.076 & 0.110 & -0.694 & 0.489 \\
Functional Benefit & 0.907 & 0.094 & 9.694 & 0.000 \\
Brand Ambassador & 0.062 & 0.087 & 0.711 & 0.479 \\
\hline
\end{tabular}

The result of the influence of sensory attributes, functional benefit, brand ambassador, and repurchase intention on brand loyalty is summarized in Table 3. The data analysis of Model 2 shows that hypotheses 4,5 , and 7 are accepted because the significance level is below 0.05 . The result of hypothesis 4 is found consistent with Sayed (2015). Customers could be very loyal with their experience and satisfaction, but will not purchase it again due to other factors, e.g. sensory attributes (Curtis et al., 2011). The result of hypothesis 5 appears to confirm the finding of (So et al., 2013). As in the context of this study, the customers find the value benefit of the product not just for good deals or convenience. The result of hypothesis 7 is found supportive of (Wijaya et al., 2018) claim. Hypothesis 6 is not significant (brand ambassador affecting brand loyalty) because the significance level is above 0.05 . The $R$-square $\left(R^{2}\right)$ of Model 2 is 0.787 which means that $78.7 \%$ of the respondents' loyalty to the brand can be described through the factors of sensory attributes, functional benefit, brand ambassador, and repurchase intention. 
Table 3. Coefficients of Model 2

\begin{tabular}{lcccc}
\hline Variable & Coefficients & Std. Error & $\boldsymbol{t}$ & Sig. \\
\hline Constant & -0.409 & -1.527 & 0.268 & 0.130 \\
Sensory Attributes & 0.269 & 3.115 & 0.086 & 0.002 \\
Functional Benefit & 0.498 & 4.827 & 0.103 & 0.000 \\
Brand Ambassador & 0.111 & 1.623 & 0.069 & 0.108 \\
Repurchase Intention & 0.375 & 4.692 & 0.080 & 0.000 \\
\hline
\end{tabular}

In the analysis further (see Table 4), the mediation effects are calculated using the procedures depicted by (Baron \& Kenny, 1986), to test whether there was a change in multiple specific process variables over the intention to repurchase would mediate the effects of sensory attributes, functional benefits, and brand ambassador on the brand loyalty. As a result, it could be concluded that the intention to repurchase is not a mediator between sensory attributes and brand loyalty. Meanwhile, intention to repurchase is a mediator between functional benefits and brand loyalty and between brand ambassador and brand loyalty.

Table 4. Testing Mediator Effects Using Multiple Regression

\begin{tabular}{cccc}
\hline Mediation & Estimate & p-value & Result \\
\hline SA x ITR $\rightarrow$ BL & -0.028 & 0.000 & No Mediation \\
FB x ITR $\rightarrow$ BL & 0.340 & 0.000 & Full Mediation \\
BA x ITR $\rightarrow$ BL & 0.023 & 0.000 & Full Mediation \\
\hline
\end{tabular}

Note: Sensory attributes (SA), intention to repurchase (ITR), brand loyalty (BL), functional benefits (FB), brand ambassador (BA)

From Figure 1, it can be implied that sensory attributes do not affect repurchase intention, while the brand ambassador factor does not have an impact on both repurchase intention and brand loyalty. From the beta value, it can be seen that functional benefit is the most important precursor to both repurchase intention and brand loyalty.

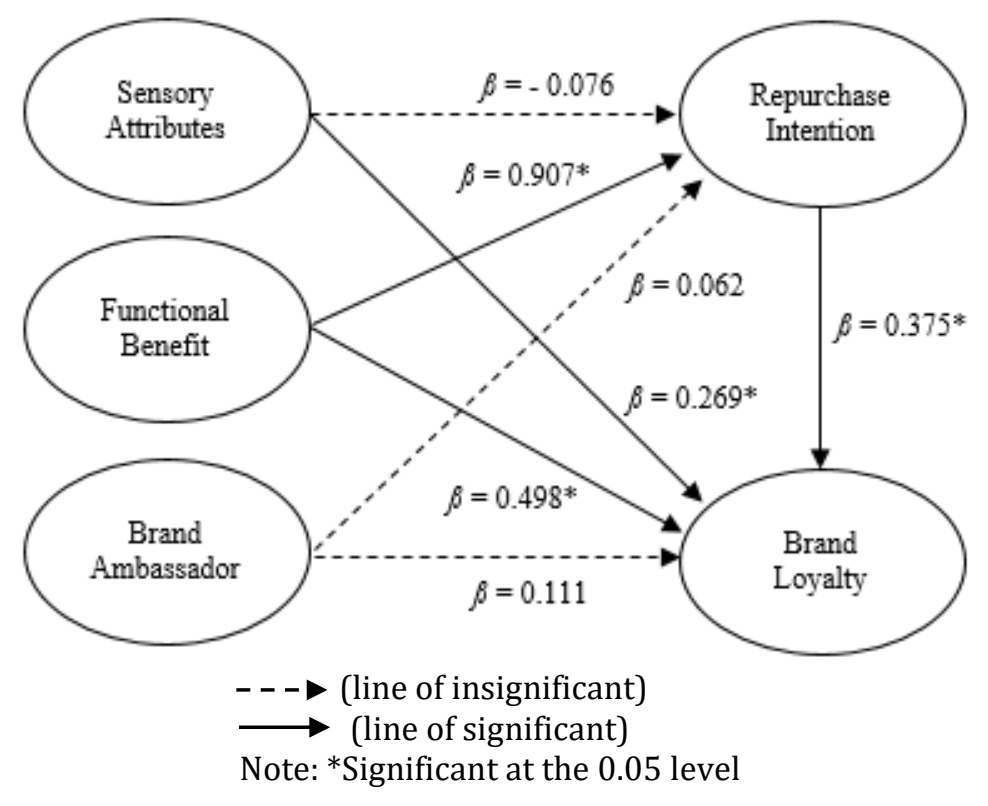

Figure 1. Structural Model

\section{Discussion}

The aim of this study is to examine the association between sensory attributes and intention to repurchase Luwak White Coffee and it was hypothesized that SA is not associated with IR. The results did not verify the hypothesis and did not empirically find an association between the two variables. Another objective of this study was to investigate the link between functional benefit and intention to repurchase 
(IR). The findings also empirically verified the hypothesis that there is a positive relationship between FB and IR. Similar finding was produced in a previous study by (Ko et al., 2011; Wiedmann et al., 2007). To retain consumers with repetitive purchases, the functional benefit has to be developed seriously by the marketing manager by stressing the importance of health benefits which promised that the product has a lower acid level, hence very safe for the gastric. The third objective of this study was to investigate the link between brand ambassador (BA) and intention to repurchase (IR) and it was hypothesized that BA is not associated with IR. The results did not verify the hypothesis and did not empirically find an association between the two variables.

The fourth objective of this study was to investigate the link between sensory attributes (SA) and brand loyalty (BL). The findings also empirically verified the hypothesis that there is a positive relationship between SA and BL. Similar findings were produced in previous studies (Brakus et al., 2009; Sayed, 2015). In order to ensure the loyalty of the consumers, marketing managers are encouraged to achieve some degree of differentiation in the brand from the competitors by using all five senses (Durmaz et al., 2018). Thus, it will strengthen the relationship between the brand and consumers on a deeper level through the human sense's involvement. The fifth objective of this study was to investigate the link between functional benefit (FB) and brand loyalty (BL). The findings also empirically verified the hypothesis that there is a positive relationship between FB and BL. The findings also endorse the results of previous study by (So et al., 2013). Therefore, based on the empirical findings of this study, it can be fairly assessed that the functional benefit of the product has an important link with their consumers' loyalty to the brand of Luwak White Coffee. This could perhaps be interpreted that consumers are discerning enough to maintain that functional benefits are required to keep the brand under consideration for repeat purchase as well as creating and sustaining consumers' loyalty. With the growing development of coffee shops springing everywhere in the country, pre-packaged coffee brands may benefit paying attention to consumers who may not be happy with the product to build brand loyalty over some time.

The sixth objective of this study was to investigate the link between brand ambassador (BA) and brand loyalty (BL) and it was hypothesized that BA is not associated with BL. The results did not verify the hypothesis and did not empirically find an association between the two variables This results line with research conducted by (Al-Shuhaibi et al., 2016; Utami, 2016). Finally, the objective of this study was to investigate the link between intention to repurchase (IR) and brand loyalty (BL). The findings also empirically verified the hypothesis that there is a positive relationship between IR and BL. The findings also endorse the results of previous study by (Consuegra, Martin et al., 2007; Knox \& Walker, 2001; Wijaya et al., 2018). Therefore, based on the empirical findings of this study, it can be fairly assessed that the repurchase intention of the product has an important link with their consumers' loyalty to the brand of Luwak White Coffee.

This perhaps could be interpreted that the challenge of the brand manager is to upgrade the consumer and build loyalty in a variety of ways. Hence, brand loyalty concepts in an emerging market could have a profound impact on practice-oriented strategies, focusing on loyalty and repeat purchase. The present study has probed into limited coverage of respondents in Jakarta. Larger area coverage would be able to provide a more precise, accurate, and comprehensive results for the study. Furthermore, future studies could also be looking at several factors such as price, packaging, and promotional events that may affect the intention of repurchase and brand loyalty.

\section{Conclusion}

Functional benefit has a significant influence on both intentions to repurchase and brand loyalty. This benefit factor is the most important precedent to both repurchase intention and brand loyalty. On the other hand, sensory attributes do not affect repurchase intention. This type of information can be important to predict or to explain the market response to luwak coffee products, and also to select which sensory attribute should be included in a sensory specification or must be considered in product quality control programs. Another important finding is that, contrary to our expectations, we do not find empirical support for the significant influence of brand ambassador on an intention to repurchase and brand loyalty. The explanation may be that customers currently expect the functional benefit in the form of healthier gastric-friendly white coffee. Moreover, the brand ambassador may not be too influential in the high buying decision among luwak coffee consumers. The relevant contributions that emerged from this study include not only bridging the aforementioned gap in the literature but also offering significant managerial implications to assist organizations to understand the importance of functional benefits toward repurchase intention and brand loyalty. 


\section{References}

Al-Shuhaibi, A. S. I., Shamsudin, F. M., \& Aziz, N. A. (2016). Developing Brand Ambassadors: The Role of Brand-centred Human Resource Management. International Review of Management and Marketing, 6, 155-161. https://www.econjournals.com/index.php/irmm/article/view/3225

Alfirahmi, A. (2019). Fenomena Kopi Kekinian di Era 4.0 ditinjau dari Marketing 4.0 dan teori Uses and Effect. Lugas: Jurnal Komunikasi, 3(1), 24-32. https://doi.org/10.31334/ljk.v3i1.410

Barahona, I., Jaimes, E. M. S., \& Yang, J.-B. (2020). Sensory attributes of coffee beverages and their relation to price and package information: A case study of Colombian customers' preferences. Food Science \& Nutrition, 8(2). https://doi.org/10.1002/fsn3.1404

Baron, R. M., \& Kenny, D. A. (1986). The moderator-mediator variable distinction in social psychological research: Conceptual, strategic, and statistical considerations. Journal of Personality and Social Psychology, 51(6), 1173-1182. https://psycnet.apa.org/1987-13085-001

Brakus, J. J., Schmitt, B. H., \& Zarantonello, L. (2009). Brand Experience: What Is It? How Is It Measured? Does It Affect Loyalty? Journal of Marketing, 73(3), 52-68. https://doi.org/10.1509/jmkg.73.3.052

Consuegra, Martin, D., Molina, A., \& Esteban, A. (2007). An integrated model of price, satisfaction and loyalty: An empirical analysis in the service sector. Journal of Product \& Brand Management, 16(7), 459-468. https://doi.org/10.1108/10610420710834913

Curtis, T., Abratt, R., \& Rhoades, D. L. (2011). Customer Loyalty, Repurchase and Satisfaction: A MetaAnalytical Review. Journal of Consumer Satisfaction, Dissatisfaction and Complaining Behavior, 24(1), 1-26. https://commons.erau.edu/db-management/18/

Durmaz, Y., Cavusoglu, S., \& Ozer, O. (2018). The effect of brand image and brand benefit on customer loyalty: the case of Turkey. International Journal of Academic Research and Social Sciences, 8(5), 528-540. https://ideas.repec.org/a/hur/ijarbs/v8y2018i5p528-540.html

Gogtay, N. J., \& Thatte, U. M. (2017). Principles of Correlation Analysis. Journal of The Association of Physicians of India, 65, 78-81. https://www.kem.edu/wp-content/uploads/2012/06/9Principles_of_correlation-1.pdf

Gupta, K., \& Stewart, D. W. (1996). Customer Satisfaction and Customer Behavior: The Differential Role of Brand and Category. Marketing Letters, 7(3), 249-263. https://doi.org/10.1007/BF00435741

Gwinner, K. P., Gremler, D. D., \& Bitner, M. J. (1998). Relational benefits in service industries: The customer's perspective. Journal of the Academy of Marketing Science, 26(2), 101-114. https://doi.org/10.1177/0092070398262002

Harris, F., \& de Chernatony, L. (2001). Corporate branding and corporate brand performance. European Journal of Marketing, 35(3/4), 441-456. https://doi.org/10.1108/03090560110382101

Jaimes, E. M. S., Torres, I. B., \& Perez-Villareal, H. H. (2015). Sensory evaluation of commercial coffee brands in Colombia. International Journal of Business and Systems Research, 9(3), 195-213. https://doi.org/10.1504/IJBSR.2015.071831

Knox, S., \& Walker, D. (2001). Measuring and Managing Brand Loyalty. Journal of Strategic Marketing, 9(2), 111-128. https://doi.org/10.1080/713775733

Ko, E., Lee, M.-A., Lee, M. Y., Phan, M., Kim, K. H., Hwang, Y. K., \& Burns, L. D. (2011). Product Attributes' Effects on Perceived Values and Repurchase Intention in Korea, USA, and France. Journal of Global Scholars of Marketing Science, 21(3), 155-166. https://doi.org/10.1080/21639159.2011.9711022

Orth, U. R., \& DeMarchi, R. (2007). Understanding the Relationships between Functional, Symbolic, and Experiential BrandBeliefs, Product Experiential Attributes, and Product Schema: Advertising-Trial Interactions Revisited. Journal of Marketing Theory and Practice, 15(3), 219-233. https://doi.org/10.2753/MTP1069-6679150303

Sayed, M. A. (2015). Does Brand Experience Build Customer's Satisfaction and Loyalty in the Automobile Industry. Journal of Marketing and Consumer Research, 15(1), 103-112.

So, J., Parsons, A., \& Yap, S. (2013). Corporate branding, emotional attachment and brand loyalty: the case of luxury fashion branding. Journal of Fashion Marketing and Management: An International Journal, 17(4), 403-423. https://doi.org/10.1108/JFMM-03-2013-0032 
Utami, E. S. (2016). Pengaruh Brand Awareness sebagai Mediasi Pengaruh Iklan Televisi Dan Brand Ambassador Terhadap Repuchase Intention Produk Kecantikan Wardah. Jurnal Ilmiah Mahasiswa FEB Universitas Brawijaya, 5(2).

Wiedmann, K.-P., Hennigs, N., \& Siebels, A. (2007). Measuring Consumers' Luxury Value Perception: A Cross-Cultural Framework. Academy of Marketing Science Review, 7(1), 1-21. https://www.questia.com/library/journal/1G1-177719439/measuring-consumers-luxury-valueperception-a-cross-cultural

Wijaya, R., Farida, N., \& Andriansyah. (2018). Determinants of Repurchase intentions at Online Stores in Indonesia. International Journal of E-Business Research, 14(3), 95-111. 